\title{
Martin Tamcke. Die Christen vom Tur Abdin. Hinführung zur Syrisch-Orthodoxen Kirche
}

Florence Jullien

\section{(2) OpenEdition}

1 Journals

\section{Édition électronique}

URL : http://journals.openedition.org/abstractairanica/40889

DOI : 10.4000/abstractairanica.40889

ISSN : 1961-960X

Éditeur :

CNRS (UMR 7528 Mondes iraniens et indiens), Éditions de l'IFRI

\section{Édition imprimée}

Date de publication : 1 décembre 2013

ISSN : 0240-8910

\section{Référence électronique}

Florence Jullien, « Martin Tamcke. Die Christen vom Tur Abdin. Hinführung zur Syrisch-Orthodoxen Kirche », Abstracta Iranica [En ligne], Volume 32-33 | 2013, document 348, mis en ligne le 01 juillet 2016, consulté le 26 septembre 2020. URL : http://journals.openedition.org/abstractairanica/40889 ; DOI : https://doi.org/10.4000/abstractairanica.40889

Ce document a été généré automatiquement le 26 septembre 2020

Tous droits réservés 


\title{
Martin Tamcke. Die Christen vom Tur Abdin. Hinführung zur Syrisch- Orthodoxen Kirche
}

\author{
Florence Jullien
}

\section{RÉFÉRENCE}

Martin Tamcke. Die Christen vom Tur Abdin. Hinführung zur Syrisch-Orthodoxen

Kirche. Frankfurt a/Main, Otto Lembeck, 2009, 210 p.

1 L'A. entreprend de retracer l'histoire mouvementée de l'Église syro-orthodoxe depuis son émergence au $\mathrm{VI}^{\mathrm{e}} \mathrm{s}$. jusqu'à nos jours : il rappelle les positionnements et les disputes théologiques, les difficultés auxquelles furent confrontés ces chrétiens dits "jacobites" sous la domination islamique, jusqu'aux persécutions encourues dans l'empire ottoman au début du $\mathrm{XX}^{\mathrm{e}}$ siècle. Il souligne l'importance de ces communautés syro-occidentales en Iran dans la diffusion du christianisme vers l'Est. Cet ouvrage constitue un excellent compendium, très complet et bien documenté, sur l'histoire et les aléas de cette communauté. En annexe, quelques textes choisis donnent un aperçu de cette riche littérature, ainsi qu'une vue d'ensemble des découpages juridictionnels des diocèses de cette Église. 


\section{AUTEURS}

\section{FLORENCE JULLIEN}

EPHE, Paris 